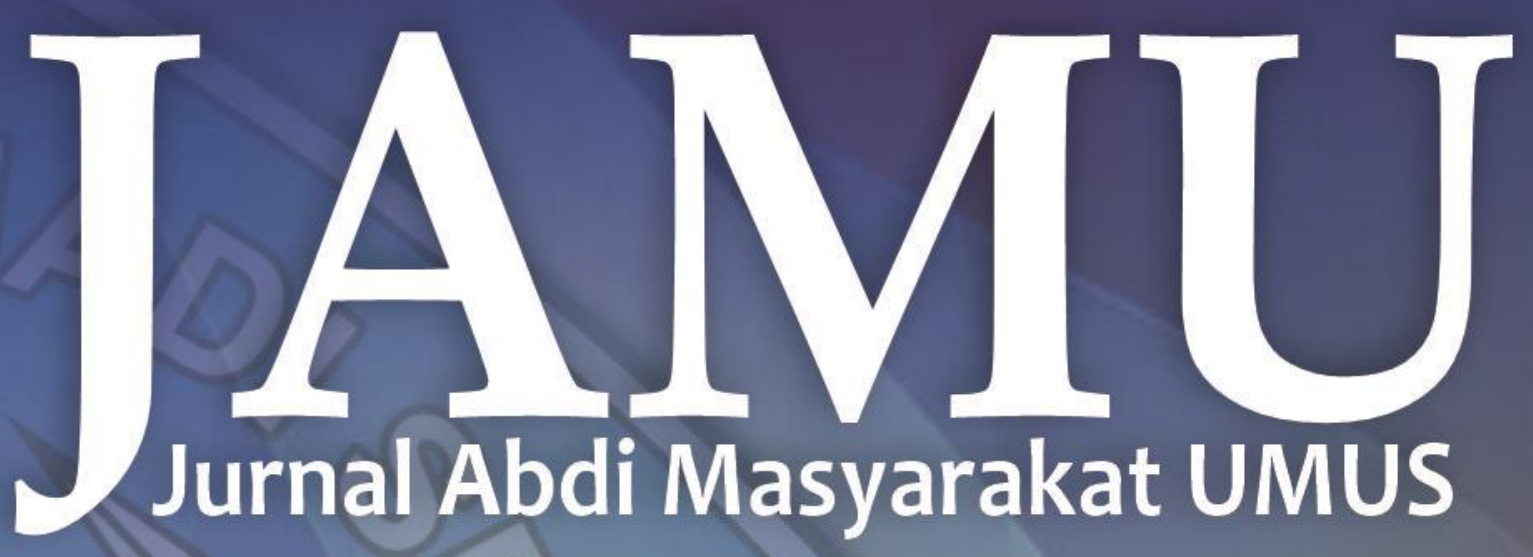




\section{EDITOR IN CHIEF}

Ubaedillah, M.Pd

\section{MANAGING EDITOR}

Harliana, ST., M.Cs

\section{PRINCIPAL CONTACT}

Rifatul Masrikhiyah, S.Tp., M.Si

\section{SUPPORT CONTACT}

Laelia Nurpratiwiningsih, M.Pd

\section{MITRA BESTARI (STAFF AHLI)}

Dr. Roby Setiadi, S.Kom., M.M (Universitas Muhadi Setiabudi, Brebes)

Otong Saeful Bachri, S.Kom., M.Kom (Universitas Muhadi Setiabudi, Brebes)

Dr. Moh. Toharudin, M.Pd (Universitas Muhadi Setiabudi, Brebes) Atikah Mumpuni, M.Pd (Universitas Muhadi Setiabudi, Brebes)

Dr. Heru Ismanto, S.Si., M.Cs (Universitas Musamus Merauke, Papua) Dr. Wuri Wuryandani, M.Pd (Universitas Negeri Yogyakarta)

Dr. Nanik Sulistyani, M.Si., Apt (Universitas Ahmad Dahlan, Yogyakarta)

Dina Rahayuning Pangestuti, S.TP., M.Gizi (Universitas Diponogoro) Jasanta Peranginangin, S.E., M.M (Sekolah Tinggi Pariwisata Sahid Surakarta)

Dr. Lili Karmela Fitriani, S.E., M.Si (Universitas Kuningan, Jawa Barat)

\section{PENANGGUNGJAWAB :}

Rektor Universitas Muhadi Setiabudi Brebes

\section{ALAMAT PENYUNTING:}

LP3M Universitas Muhadi Setiabudi Brebes.

Jalan Pangeran Diponogoro KM 2 Wanasari Brebes - Jawa Tengah 52252. Telp (0283) 6199000 


\section{JAMU}

Jurnal Abdi Masyarakat UMUS

\section{KATA PENGANTAR}

Assalamualaikum Wr, Wb

Puji syukur kehadirat Allah SWT atas anugrahnya sehingga jurnal edisi kali ini dapat terbit. Sebelumnya kami ingin mengucapkan terimakasih banyak kepada dosen/peneliti/profesi yang telah mengirimkan artikelnya kepada dewan redaksi untuk dapat dipublish pada jurnal yang kami kelola. Semua artikel yang masuk kepada dewan redaksi telah melalui proses review oleh mitra bestari dan tim dewan redaksi, segala proses revisi dan redaksional juga telah dilakukan oleh penulis sebelum jurnal ini diterbitkan. Segala bentuk kritik dan saran yang membangun dari pembaca / peneliti yang dikirimkan sangat kami harapkan demi melakukan pembenahan jurnal yang kami kelola. Akhir kata kami menghaturkan terimakasih banyak kepada semua pihak yang sudah terlibat dalam proses penerbitan jurnal ini.

Wassalamualaikum wr wb.

Ketua Dewan Redaksi 


\section{DAFTAR ISI}

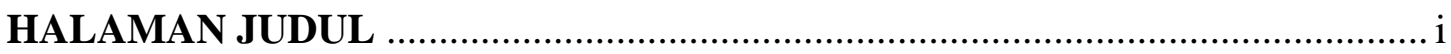

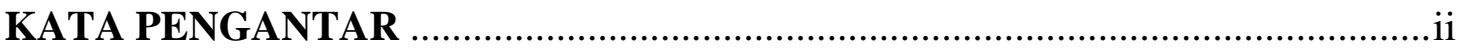

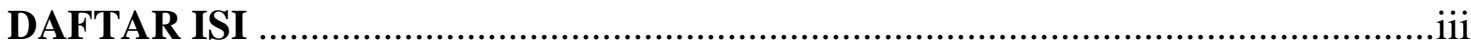

Pemberdayaan Anak Usia Sekolah Dalam Menumbuhkan Nilai Karakter Melalui Strategi Pembiasaan Di PPSA Tegal

Moh. Toharudin ${ }^{1}$, Laelia Nurpratiwiningsih ${ }^{2}$, Gian Fitralisma ${ }^{3}$

${ }^{(1,2)}$ Program Studi Pendidikan Guru Sekolah Dasar, Fakultas Keguruan dan Ilmu Pendidikan Universitas Muhadi Setiabudi

${ }^{3}$ Program Studi Manajemen, Fakultas Ekonomi dan Bisnis, Universitas Muhadi Setiabudi) $\quad$ 1-7

Menstimulasi Kemampuan Berbicara Pada Anak Usia Dini Berbasis Media Dongeng Agnes Apryliana ${ }^{1}$, Kiki Purwati ${ }^{2}$

${ }^{(1,2)}$ Program Studi Pendidikan Bahasa dan Sastra Indonesia, Fakultas Keguruan dan Ilmu Pendidikan, Universitas Muhadi Setiabudi)

Pemanfaatan E-Commerce Terhadap Penjualan Kendang Jimbe Blitar Harliana $^{1)}$, Roby Setiadii ${ }^{2}$, Otong Saeful Bachri ${ }^{3)}$, Khalid Iskandar ${ }^{4)}$, Gagas Prasetya ${ }^{5)}$ ${ }^{(1,3,5)}$ Program Studi Teknik Informatika, Fakultas Teknik, Universitas Muhadi Setiabudi ${ }^{2,4)}$ Program Studi Manajemen, Fakultas Ekonomi dan Bisnis, Universitas Muhadi Setiabudi) 15-20

Manajemen Tatakelola BUMDES: Mengelola Pemasaran Produk

Andi Yulianto ${ }^{1)}$, Mukson ${ }^{2)}$, Otong Saeful Bachri ${ }^{3)}$, Slamet Bambang Riono ${ }^{4)}$, Yenny Ernitawati ${ }^{5)}$ ${ }^{(1,2,4)}$ Program Studi Manajemen, Fakultas Ekonomi dan Bisnis, Universitas Muhadi Setiabudi ${ }^{5)}$ Program Studi Akuntansi, Fakultas Ekonomi dan Bisnis, Universitas Muhadi Setiabudi)

${ }^{3)}$ Program Studi Teknik Informatika, Fakultas Teknik, Universitas Muhadi Setiabudi)

Penggunaan Kartu Huruf dan Peramainan Mencari Kartu Huruf Untuk Peningkatan Pengenalan Huruf

Muhammad Toha $^{1)}$, Armyta Puspitasari ${ }^{2}$, Ubaedillah ${ }^{3)}$, Farhan Saefudin Wahid ${ }^{4)}$, Laelia Nurpratiwiningsih ${ }^{5}$

${ }^{(1,3)}$ Program Studi Pendidikan Bahasa dan Sastra Indoensia, Fakultas Keguruan dan Ilmu Pendidikan, Universitas Muhadi Setiabudi,

2)Teknologi Bangunan dan Jalur Perkretaapian, Politeknik Perkretaapian Indonesia,

${ }^{4,5}$ Program Studi Pendidikan Guru Sekolah Dasar, Fakultas Keguruan dan Ilmu Pendidikan, Universitas Muhadi Setiabudi)

${ }^{3)}$ Program Studi Manajemen, Fakultas Ekonomi dan Bisnis, Universitas Muhadi Setiabudi)

$28-33$ 


\section{Menumbuhkan Sikap Sadar Lingkungan Bagi Anak Usia Sekolah Dasar}

Laelia Nurpratiwiningsih ${ }^{1)}$, Teguh Arifianto ${ }^{2)}$, Wildan Qosid ${ }^{3)}$, Ubaedillah ${ }^{4)}$

(1,3)Program Studi Pendidikan Guru Sekolah Dasar, Fakultas Keguruan dan Ilmu Pendidikan, Universitas Muhadi Setiabudi,

${ }^{2)}$ Teknologi Elektro Perkretaapian, Politeknik Perkretaapian Indonesia,

$\left({ }^{4}\right.$ Program Studi Pendidikan Bahasa dan Sastra Indonesia, Fakultas Keguruan dan Ilmu Pendidikan,

Universitas Muhadi Setiabudi)

Peningkatan Pengetahuan Mengenai Manfaat Pangan Probiotik dan Prebiotik Bagi Kesehatan

Rifatul Masrikhiyah ${ }^{1)}$, Henry Widya Prasetya ${ }^{2)}$, Ubaedillah $^{3)}$, Rifqi Ferry Balfas ${ }^{4}$, Susi Yulianingsih ${ }^{5)}$ ${ }^{1,5}$ Program Studi Ilmu Gizi, Fakultas Kesehatan, Universitas Muhadi Setiabudi,

${ }^{2)}$ Teknologi Mekanika Perkretaapian, Politeknik Perkretaapian Indonesia,

${ }^{3}$ Program Studi Pendidikan Bahasa dan Sastra Indonesia, Fakultas Keguruan dan Ilmu Pendidikan, Universitas Muhadi Setiabudi,

4)Program Studi Ilmu Gizi, Fakultas Ilmu Kesehatan, Universitas Muhadi Setiabudi) $\quad$ 42-46

\section{Pelatihan Wawancara Kerja Dalam Bahasa Inggris Bagi Siswa SMK Menggunakan}

Metode Demonstrasi

Ubaedillah $^{1)}$, Damar Isti Pratiwi ${ }^{2)}$, Mukson $^{3)}$, Rifatul Masrikhiyah ${ }^{4)}$, Laelia Nurpratiwiningsih ${ }^{5)}$

( ${ }^{1}$ Program Studi Pendidikan Bahasa dan Sastra Indonesia, Fakultas Keguruan dan Ilmu Pendidikan, Universitas Muhadi Setiabudi,

2) Teknologi Mekanika Perkretaapian, Politeknik Perkretaapian Indonesia.

${ }^{3}$ Program Studi Manajemen, Fakultas Ekonomi dan Bisnis, Universitas Muhadi Setiabudi,

${ }^{4)}$ Program Studi Ilmu Gizi, Fakultas Ilmu Kesehatan, Universitas Muhadi Setiabudi

${ }^{5)}$ Program Studi Guru Sekolah Dasar, Fakultas Keguruan dan Ilmu Pendidikan, Universitas Muhadi Setiabudi) 


\title{
PENINGKATAN PENGETAHUAN MENGENAI MANFAAT PANGAN PROBIOTIK DAN PREBIOTIK BAGI KESEHATAN
}

\author{
Rifatul Masrikhiyah*1, Henry Widya Prasetya ${ }^{2}$ Ubaedillah $^{3}$, Rifqi Ferry Balfas ${ }^{4}$, Susi \\ Yulianingsih ${ }^{5}$ \\ ${ }^{1}$ Program Studi S-1 Ilmu Gizi, Fakultas Ilmu Kesehatan, Universitas Muhadi Setiabudi Brebes, \\ Indonesia \\ ${ }^{2}$ Teknologi Mekanika Perkretaapian, Politeknik Perkretaapian Indonesia, \\ ${ }^{3}$ Program Studi S-1 Pendidikan Bahasa dan Sastra Indonesia, Fakultas Keguruan dan Ilmu \\ pendidikan, Universitas Muhadi Setiabudi Brebes, Indonesia. \\ ${ }^{4}$ Program Studi D-3 Farmasi, Fakultas Ilmu Kesehatan, Universitas Muhadi Setiabudi Brebes, \\ Indonesia \\ ${ }^{5}$ Program Studi S-1 Ilmu Gizi, Fakultas Ilmu Kesehatan, Universitas Muhadi Setiabudi Brebes, \\ Indonesia \\ e-mail: *11rifatul.masrikhiyah@gmail.com, ${ }^{2}$ henry@ppi.ac.id, ${ }^{3}$ ubaedillah@umus.ac.id, \\ ${ }^{4}$ rifqi.fb@umus.ac.id ${ }^{5}$ susi.y@mhsumus.ac.id
}

\begin{abstract}
Probiotics are foods or drinks that contain live bacteria that benefit or benefit health, whereas prebiotic is a foodstuff that is not digestible by digestive enzymes and can support the growth of good bacteria in the intestines. The magnitude of probiotic food benefits and prebiotics for health as reported by Healthline, prebiotic food and probiotics are effective for treating diarrhea, irritable bowel syndrome, allergic disorders, but the enrichment regarding probiotic and prebiotic food is very lacking. This activity aims to improve the knowledge of the probiotic food benefits and prebiotics for health. . PkM was held in the village Sidamulya Wanasari Kabupeten Brebes subdistrict in November 2019. The subject that follows the activity of 25 mothers-Ibu Posyandu Kader Sidamulya Village. This activity consists of 3 stages including: preparation stage, implementation stage and interview stage. Data obtained from pretests and posttest results and discussions. Results of this activity is an increase in the knowledge of mothers about the benefits of food probiotics and prebiotic for health, there is an increase from $4 \%$ to $68 \%$.
\end{abstract}

Keywords: probiotics, prebiotics, bacteria, functional food

\section{PENDAHULUAN}

Pada era globalisasi ini, masyrakat mulai sadar akan kesehatan dimana dalam pemenuhan makanan untuk keluarga khususnya selain rasanya enak harus dapat bermanfaat bagi kesehatan yang sering disebut dengan pangan fungsional. Pangan probiotik dan prebiotik termasuk kedalam makanan fungsional karena manfaatnya bagi kesehatan terutama kesehatan pencernaan. Menurut FAO (Food and Agriculture Organization), probiotik adalah suatu mikroorganisme hidup yang bermanfaat bagi kesehatan inang (baik itu hewan maupun manusia). Contoh pangan probiotik yaitu produk produk susu fermentasi seperti yoghurt, yakult dadih, kefir dan lain sebagainya. Prebiotik merupakan makanan yang tidak dapat dicerna, yang membawa manfaat kepada host dengan secara selektif menstimulasi pertumbuhan dan atau aktivitas bakteri yang bermanfaat terbatas di dalam usus dan meningkatkan kesehatan manusia (A. Pertiwi, 2008). Bahan makanan yang 
merupakan prebiotik dapat berasal dari sayur, umbi-umbian, maupun buahbuahan.Salah satu contoh pangan prebiotik paling potensial adalah pangan prebiotik yang berasal dari karbohidrat seperti inulin. Inulin tergolong sebagai prebiotik karena mampu melewati saluran pencernaan atas dan mencapai usus besar, sehinggga dianggap juga sebagai "colonic foods" bagi mikroflora usus (P. Reski Praja, 2010)

Pemenuhan asupan makanan yang seimbang atau gizi seimbang dipengaruhi oleh tingkat pengetahuan masyarakat terhadap makanan seimbang atau gizi seimbang. Upaya untuk meningkatkan pengetahuan masyarakat perlu diadakannya edukasi atau pendidikan gizi pada masyarakat. Menurut beberapa peneliti bahwa pendidikan gizi mampu meningkatkan pengetahuan gizi (Verarica, 2016), ada perbedaan antara pengetahuan sebelum dan sesudah pemberian edukasi gizi dengan nilai $\mathrm{p}=0,000(\mathrm{p}<0,05)$ (Sukmawati, 2013)

Pengetahuan mengenai pangan yang tergolong prebiotik dan probiotik masih sangat rendah, padahal masyarakat sudah cukup familiar terhadap produk produk probiotik seperti yakult akan tetapi tidak mengerti akan manfaatnya. Pangan prebiotik dan probiotik yang bermanfaat bagi kesehatan saluran pencernaan. Salah satu masalah kesehatan saluran pencernaan adalah diare. Diare masih merupakan masalah kesehatan utama pada anak terutama balita di negara berkembang karena angka kesakitan dan kematian yang tinggi. Survei morbiditas yang dilakukan oleh Subdit Diare, Departemen Kesehatan dari tahun $2000 \mathrm{~s} / \mathrm{d} 2010$ terlihat kecenderungan insidens naik. Pada tahun 2000 IR penyakit Diare 301/ 1000 penduduk, tahun 2003 naik menjadi 374 /1000 penduduk, tahun 2006 naik menjadi $423 / 1000$ penduduk dan tahun 2010 menjadi 411/1000 penduduk. Kejadian Luar Biasa (KLB) diare juga masih sering terjadi, dengan CFR yang masih tinggi. Pada tahun 2008 terjadi KLB di 69 Kecamatan dengan jumlah kasus 8133 orang, kematian 239 orang (CFR 2,94\%).
Tahun 2009 terjadi KLB di 24 Kecamatan dengan jumlah kasus 5.756 orang, dengan kematian 100 orang (CFR 1,74\%), sedangkan tahun 2010 terjadi KLB diare di 33 kecamatan dengan jumlah penderita 4204 dengan kematian 73 orang (CFR 1,74 $\%$.) (Soepardi, 2011).

Salah satu cara untuk mengetasi diare dengan mengkonsumsi pangan probiotik. Terdapat banyak laporan tentang penggunaan probiotik dalam tata laksana diare akut pada anak. Isolauri tahun 1991, meneliti 71 anak yang dirawat dengan diare akut. Pasien secara acak diberikan susu yang difermentasi dengan Lactobacillus GG, atau Lactobacillus GG diberikan sebagai bubuk kering atau diberikan yoghurt yang telah dipasteurisasi sebagai plasebo. Lama diare berkurang dari 2,4 hari pada kelompok plasebo menjadi 1,4 hari pada kelompok yang disuplementasi. Delapan puluh dua persen diare disebabkan oleh rotavirus. Ternyata reduksi lamanya diare lebih nyata bila yang dianalisis hanya kasus diare yang disebabkan rotavirus. Penelitian juga dilakukan untuk menilai dampak probiotik terhadap pencegahan diare pada anak. Saavedra tahun 1994 memperlihatkan bahwa Bifidobacteria dan S. thermophilus, bila diberikan bersamasama, menurunkan angka kejadian diare dari $31 \%$ menjadi $7 \%$ pada sekelompok bayi yang dirawat di rumah sakit bila dibandingkan dengan plasebo.

Berdasarkan gambaran permasalahan yang telah dijabarkan maka dapat ditarik kesimpulan bahwa salah satu penyebab permasalahan kesehatan adalah kurang pengetahuan mengenai pangan yang bermanfaat bagi kesehatan seperti pangan prebiotik dan probiotik. Permasalah tersebut yang melatarbelakangi dilakukannya penyuluhan mengenai "Peningkatan Pengetahuan Mengenai Manfaat Pangan Probiotik Dan Prebiotik Bagi Kesehatan" pada ibu ibu kader puskesmas di Desa Sidamulya, Kecamatan Wanasari, Kabupaten Brebes.

\section{METODE PELAKSANAAN}

Program penyuluhsn dilaksanakan di kantor Desa Sidamulya Kecamatan 
Wanasari Kabupaten Brebes, Jawa Tengah. PkM ini diikuti oleh kader kader posyandu yang berjumlah 25 orang dan 10 mahasiswa (yang secara sukarelawan) yang terlibat dalam PkM ini. PkM dilaksanakan pada bulan November 2019. Target atau sasaran PkM ini yaitu kader kader posyandu yang ada di Desa Sidamulya dengan tujuan kader kader desa dapat mensosialisasikan hasil PkM yang telah diikutinya ke masyarakat Desa Sidamulya, khususnya ibu ibu rumah tangga yang secara langsung sebagai perencana menu makan keluarga di keluarga mereka masing masing.

Pelaksanaan kegiatan PkM ini menggunakan metode ceramah dengan bantuan alat peraga berupa gambar dengan tujuan untuk mempermudah pengenalan pangan prebiotik dan probiotik, menurut Warman (2019) pada PkM pelatihan peningkatan kemampuan bahasa inggris pada anak anak panti asuhan melalui pemberdayaan mahasiswa dapat ditingkatkan dengan metode ceramah menggunaan alat bantu berupa buku. Pelaksanaan kgiatan ini dibagi menjadi 3 tahapan:

Tahap I : Persiapan

Pada tahap ini meliputi merancang dan mempersiapkan bahan maupun alat yang akan digunakan untuk kegiatan PkM seperti gambar, pangan prebiotik dan probiotik, kuesioner untuk wawancara, LCD, Laptop, Handout dan alat tulis. Melakukan koordinasi secara menyeluruh dengan anggota dan mahasiswa yang mengikuti kegiatan ini.

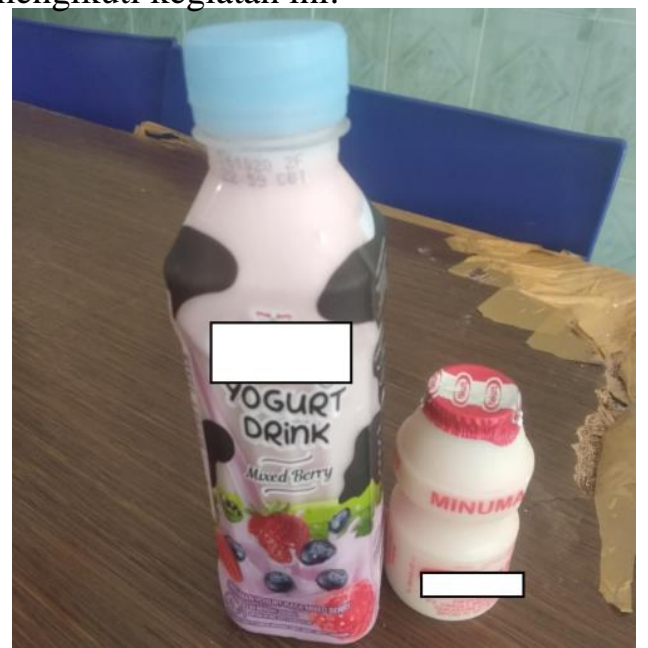

Gambar 1. Produk Probiotik

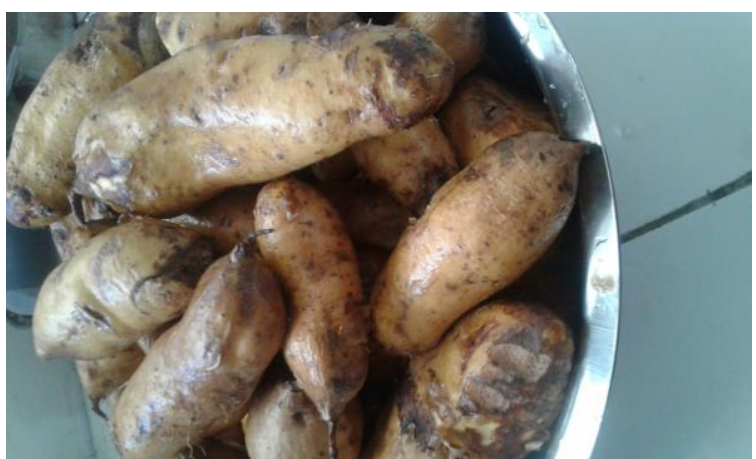

Gambar 2. Pangan Prebiotik

Tahap II: pelaksanaan kegiatan.

Pelaksanaan kegiatan dilakukan pada bulan November 2019 yang dilaksanakan sebanyak 2 kali pertemuan. Pertemuan pertama meliputi wawancara dan pembagian kuesioner; dan Ceramah. Wawancara dan pembagian kuesioner yang telah dirancang oleh tim yang terlibat dalam kegiatan ini. Ceramah dilakukan dengan bantuan gambar, LCD, contoh pangan prebiotik dan prebiotik. Meteri ceramah meliputi definisi probiotik, prebiotik dan simbiotik; manfaat pangan probiotik dan prebiotik; dan contoh produk probiotik dan pangan prebiotik. Pelaksanaan Kegiatan dimulai dengan wawancara dan pembagian kuesioner mengenai pangan prebiotik dan probiotik beserta manfaatnya bagi kesehatan selama 30 menit yang kemudian data kuesioner dikumpulkan untuk dilakukan evaluasi. Wawancara dilakukan dengan tujuan untuk mengetahui seberapa paham dan seberapa jauh pengetahuan ibu ibu kader Desa Sidamulya mengenai pangan prebiotik dan probiotik beserta manfaatnya bagi kesehata sebelum dilakukan ceramah dan diskusi mengenai pangan probiotik dan prebiotik. Sesi Ceramah dimulai setelah sesi wawancara dan pengisian kuesioner selesai. Ceramah dilakukan dengan cara memberikan informasi secara oral kepada peserta PkM yang kemudian dilanjutkan dengan sesi diskusi. Diskusi dilaksanakan dengan memberkan waktu kepada peserta PkM untuk memberikan pertanyaan. Pertanyaan dibagi menjadi 3 termin yang kemudian pertanyaan pertanyaan tersebut dijawab oleh penceramah atau narasumber. 
Tahap III: pelaksanaan wawancara setelah pelaksanaan kegiatan

Wawancara dilakukan seminggu setelah dilaksanakan kegiatan kepada peserta yang telah mengikuti kegiatan PkM di Desa Sidamulya. Tujuan dilakukan wawancara, yakni untuk mengetahui pengaruh pelaksanaan kegiatan penyuluhan mengenai "Peningkatan Pengetahuan Mengenai Manfaat Pangan Probiotik Dan Prebiotik Bagi Kesehatan” di Desa Sengon. Tahap IV: Evaluasi

Pada tahap ini, tim malakukan evaluasi kegiatan dengan membandingkan hasil wawancara dan pengisian kuesioner sebelum atau Pre-Test dan sesudah atau Post-Test dilakukan kegiatan PkM Peningkatan Pengetahuan Mengenai Manfaat Pangan Probiotik Dan Prebiotik Bagi Kesehatan.

\section{HASIL DAN PEMBAHASAN}

Pelaksanaan PkM yang dilakukan di Desa Sidamulya dengan sasaran kader kader posyandu Desa Sidamulya mengenai pangan probiotik dan prebiotik menghasilkan peningkatan pengetahuan kader kader posyandu Desa Sidamulya. Peningkatan tersebut dapat dilihat pada tabel 1 .

Tabel 1. Hasil Pre-Test dan Post-Test Kader Kader Posyandu Desa Sidamulya Nilai Rata Rata (\%)

\begin{tabular}{cc}
\hline Pre-Test & Post-Tes \\
\hline $\mathbf{4}$ & 68 \\
\hline
\end{tabular}

Pada awal kegiatan dilakukan wawancara dan pengisian kuesiner mengenai pengetahun pangan probiotik dan prebiotik ternyata hanya sebagian kecil yang mampu menjawab dan mengisi kuesioner dengan benar hanya ada 1 orang yang mampu menjawab dengan tepat sedangkan 24 orang laiinya menjawab dengan salah mengenai pangan probiotik dan prebiotik. Seminggu setelah pelaksanaan kegiatan dilakukan wawancara dan pengisian kuesioner kembali untuk mengetahui adanya peningkatan atau tidak pengetahuan setelah dilakukan kegiatan, ternyata terdapat peningkatan yang cukup signifikan yaitu yang awalnya hanya 1 orang atau 4\% saja dari seluruh peserta PkM yang paham atau mengerti mengenai pangan probiotik dan prebiotik menjadi 17 orang atau $68 \%$ yang paham akan pangan probiotik dan prebiotik.

Pelaksanaan kegiatan berjalan dengan cukup berhasil dan cukup kondusif. Hal tersebuts dapat terlihat dari banyaknya peserta yang mengikuti kegiatan PkM tersebut dan antusias peserta dalam memberikan pertanyaan. Awalnya kegiatan tersebut direncanakan hanya diikuti oleh 20 kader atau peserta yang mengikuti karena antusiasme dari peserta akhirnya ditambahkan 5 peserta menjadi 25 peserta. Para peserta sangat kooperatif terlihat pada saat diadakan wawancara dan pengisian kuesioner berjalan sangat lancar dan tepat waktu dan pada saat dilakukan wawancara seminggu setelah kegiatan dimana seluruh peserta yang mengikuti kegiatan PkM bersedia untuk kumpul kembali dan bersedia untuk wawancara dan mengisi kuesiner kembali dengan senang hati.

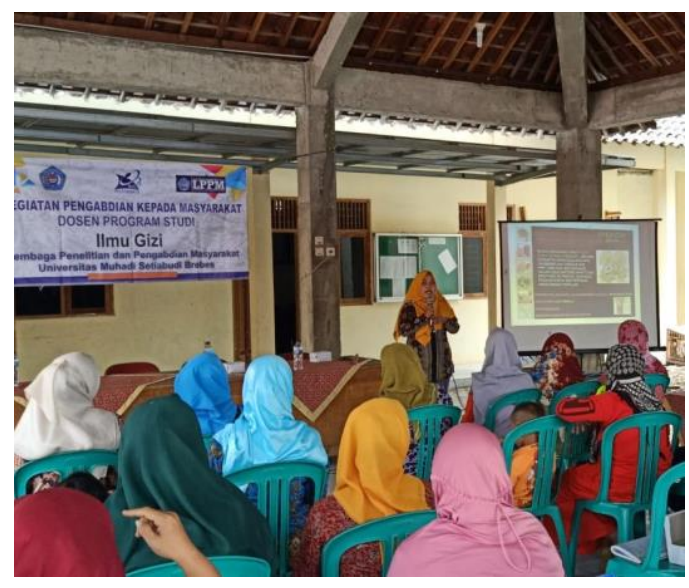

Gambar 3.Suasana Ceramah mengenai pangan probiotik dan prebiotik

Pelaksanaan Kegiatan ini cukup berhasil dimana tujuan dari kegiatan $\mathrm{PkM}$ ini tercapai yaitu adanya peningkatan pengetahuan mengenai manfaat Pangan probiotik dan prebiotik bagi kesehatan. Dimana pada awal kegiatan hanya terdapat $4 \%$ peserta yang tahu mengenai pangan probiotik dan prebiotik yang kemudian meningkat menjadi $68 \%$. 


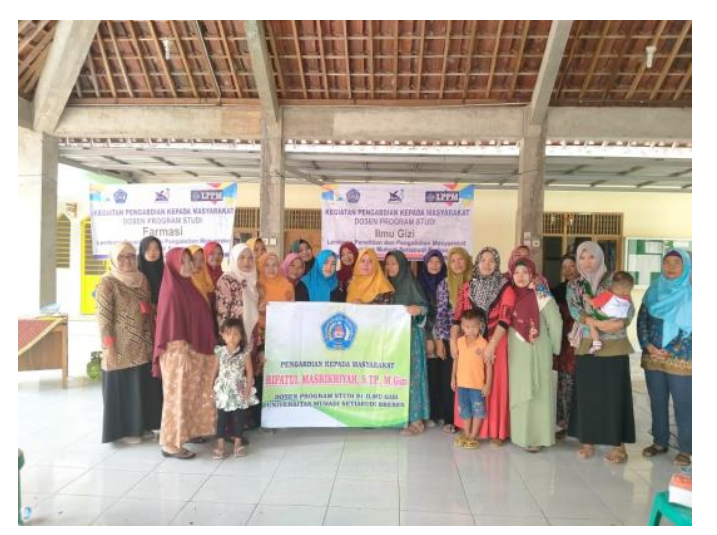

Gambar 4. Suasana sebelum acara ditutup (Seminggu setelah dilakukan kegiatan PkM)

\section{KESIMPULAN}

Terdapat peningkatan pengetahuan yang signifikan setelah mengenai pangan probiotik dan prebiotik beserta manfaatnya bagi kesehatan setelah diadakan kegiatan PkM mengenai Upaya Peningkatan Pengetahuan Mengenai Manfaat Pangan Probiotik Dan Prebiotik Bagi Kesehatan di Desa Sidamulya dari $4 \%$ menjadi $68 \%$ dari total peserta yang mengikuti kegiatan PkM.

\section{UCAPAN TERIMAKASIH}

Terimakasih kepada kepala Desa Sidamulya dan Bidan Desa Sidamulya yang berkenan membantu dan memfasilitasi dalam kegiatan PkM, serta rekan rekan sejawat dan mahasiswa ilmu gizi Universitas Muhadi Setiabudi yang telah membantu dalam pelaksanaan kegiatan PkM.

\section{DAFTAR PUSTAKA}

A. Pertiwi, "Profil Mikloflora Feses dan Usus Tikus Putih (Rattus norvegicus) dengan Konsumsi Daging yang Difermentasi oleh Lactobacillus plantarum," Institut Pertanian Bogor, 2008.
Isolauri $\mathrm{E}$, Juntunen $\mathrm{M}$, Rautanen $\mathrm{T}$, Sillanaukee P, Koivula T. A human Lactobacillus strain Lactobacillus GG promotes recovery from acute diarrhea in children. Pediatrics 1991; 88:90-7.

P. Reski Praja, "Pati Resisten dan Sifat Fungsional Tepung Pisang Tanduk (Musa paradisiaca formatypica) yang Dimodifikasi Melalui Fermentasi Bakteri Asam Laktat dan Pemanasan Otoklaf," Institut Pertanian Bogor, 2010.

Saavedra JM, Bauman NA, Oung I, Perman JA, Yolken RH. Feeding of Bifidobacterium bifidum and Streptococcus thermophillus to infants in hospital for prevention of diarrhea and sheding of rotavirus. Lancet 1994; 344:1046-9.

Silalahi, V., Aritonang, E., \& Ashar, T. (2016). Potensi pendidikan gizi dalam meningkatkan asupan gizi pada remaja putri yang anemia di kota medan. KEMAS: Jurnal Kesehatan Masyarakat, 11(2), 295301.

Soepardi, Jane. 2011. Situasi Diare di Indonesia. Buletin Jendela Data dan Informasi Kesehatan, Volume 2, Triwulan II. Jakarta: Kemeterian Kesehatan RI

Thasim, S., Syam, A., \& Najamuddin, U. (2013). Pengaruh Edukasi Gizi Terhadap Perubahan Pengetahuan dan Asupan Zat Gizi Pada Anak Gizi Lebih di SDN Sudirman I Makassar Tahun 2013. Makassar: FKM UNHAS.

Warman, J. S., Mardian, V., Suryani, L., \& Irwan, F. R. F. I., 2019. Program Pelatihan Penigkatan Kemampuan Bahasa Inggris Anak-Anak Panti Asuhan Melalui Pemberdayaan Mahasiswa. Dinamisia: Jurnal Pengabdian Kepada Masyarakat, 3(2), 280-285 